\title{
Ambient Temperature and Mortality Due to External Causes: A Systematic Review
}

\author{
Omid Aboubakri' ${ }^{1}$, Narges Khanjani ${ }^{2 *}$, Hamidreza Shoraka ${ }^{1}$ \\ ${ }^{1}$ Department of Biostatistics and Epidemiology, School of Public Health, Kerman University of Medical Sciences, Kerman, Iran \\ ${ }^{2}$ Environmental Health Engineering Research Center, Kerman University of Medical Sciences, Kerman, Iran \\ Email: *n_khanjani@kmu.ac.ir
}

How to cite this paper: Aboubakri, O., Khanjani, N. and Shoraka, H. (2018) Ambient Temperature and Mortality Due to External Causes: A Systematic Review. Occupational Diseases and Environmental Medicine, 6, 81-94.

https://doi.org/10.4236/odem.2018.63007

Received: April 30, 2018

Accepted: August 5, 2018

Published: August 8, 2018

Copyright $\odot 2018$ by authors and Scientific Research Publishing Inc. This work is licensed under the Creative Commons Attribution International License (CC BY 4.0).

http://creativecommons.org/licenses/by/4.0/

\begin{abstract}
Background: External causes include accidents, injuries or health problems that arise immediately after accidents or other external factors. The purpose of this review was to collect information about the relation between temperature and mortality due to external causes. Methods: A systematic search of articles was conducted in PubMed, Scopus, Science Direct, Embase, and Web of Science until January 2017, with no restriction. Broad searches were conducted in all fields, using key words related to ambient temperature exposure and deaths due to external causes. Results: Nine articles were included in the study. Except two articles, one of which had been designed in a cross-sectional way and the other that was retrospective, the rest of the articles were ecological. The outcomes reported were heterogeneous and different metrics had been used in the results; therefore conducting of meta-analysis was not possible. Five articles had found direct and significant relations between high temperature and deaths due to external causes. Only one study found no relation. In the case of cold, one study showed that the proportion of death due to external causes was low during cold waves. Another study showed that there was no relation between cold waves and mortality due to external causes. But one article showed that death due to external causes increased on cold days, significantly. Conclusion: The results of this systematic review showed that high temperatures (heat) were more likely to cause mortality due to external causes than low temperatures (cold). Due to the small number of studies in this field, especially in the context of cold and death due to external causes, it is difficult to make robust conclusions.
\end{abstract}

\section{Keywords}

Cold, Death, Heat, High Temperature 


\section{Introduction}

Many studies have shown the adverse effects of temperature on human mortality due to cardiovascular, respiratory diseases, or all causes [1] [2] [3] [4] [5]. There is also evidence that shows the effect of atmospheric conditions on human mortality. This evidence is mainly related to the effects of temperature, especially heat waves [6] [7]. External causes, which account for a large proportion of the causes of death in some countries, include accidents, injuries or situations [8]. The importance of these factors on mortality and burden of diseases has led to the conduct of many studies in this field. Hajat et al. [9] examined the relation between temperature and mortality due to external causes in the UK. Basagana et al. [10] also examined this relation in Catalonia, Spain. Both studies have shown that high temperatures are associated with increased death due to external causes.

Death due to external causes includes the codes V0 - Y98 and E800 - E998 in the International Classification of Diseases, version 10 and version 9 respectively. These categories involve many intentional and unintentional injuries. Intentional injuries include intentional murder or suicide by self-immolation, poisoning, hanging, drowning, and etc. Unintentional injuries include traffic accidents, falls, electrical shock, and etc. The above causes are classified in Chapter 20 of the ICD10 book. External causes also cause damage to various areas of the body which are known as the consequences of external causes. These consequences are classified in Chapter 19 of the ICD10 book [11] [12].

Several studies have examined the effect of temperature on death due to external causes, separately [13] [14] [15]. There are also systematic reviews that have assessed certain causes, separately. For example, in a review conducted by Kampe et al., the relation between temperature and only unintentional injuries has been investigated [16].

In general, studies that examine the effect of climate on death or disability due to external causes can be divided into two groups. One group investigates death due to all external causes together instead of investigating deaths due to external causes separately based on each specific cause. The other group, studies deaths due to external causes based on each specific cause separately. It is possible that no significant relation appears between temperature and death due to specific external causes analyzed separately, but significant relations appear between temperature and death due to all the external causes together [17], because of the increased sample size. Also there are studies that although have studied human mortality and temperature, but have excluded deaths due to external causes [18] [19] [20]. Excluding mortality due to external causes may lead to problems in climate studies. For example, by excluding deaths due to external causes from all causes of death, the effect of temperature on death due to all cause will be underestimated in countries where mortality is high due to external causes.

Evidence about a relation between deaths due to external causes and temperature will help both researchers who study climate change and death and policy 
makers to development plans for preventing death. The purpose of this review article is to summarize the available information about the relation between temperature and death due to all external causes.

\section{Methods}

\subsection{Search Strategy and Selection Criteria}

A systematic search was conducted in PubMed, Scopus, Science Direct, Embase, and Web of Science; until January 2017 with no restriction on language, time and location. Climate, temperature, heat, cold, weather, hot, and ambient temperature were the key words used for exposure. The key word "external causes" was used as the outcome of this study. The search strategy has been shown in Table 1 and the search strategy in each database has been shown in Supplementary (Table S1). In addition to searching the mentioned databases, the reference list of included articles was also reviewed.

Articles that reported the relation of temperature with deaths due to specific external causes, were not included in this study. Many studies have been conducted about certain types of deaths due to external causes such as suicide and temperature studies [21] [22]. Review articles have also been done about this topic [23] [24]. However, the purpose of this article was to review the studies about death due to all external causes together, not death due to specific causes among external causes.

Articles with different designs were included in this review, if they had 1) an indicator as exposure to outside temperature, 2) mortality due to external causes as the outcome, 3) and the outcome had been investigated in humans. Articles were excluded if they 1) had assessed only one type of death due to external causes out of all external causes, 2) had assessed non external causes, 3) or had defined a medical visit or morbidity as the outcome.

\subsection{Study Selection and Their Data}

The title and abstract of the retrieved articles were reviewed separately by two authors of the study (OA, HS). Then duplicate items were deleted based on author, title and year using End Note X6. The relevance of articles was determined initially based on the title and abstract and irrelevance articles were deleted. After that, the full text of the ambiguous articles was downloaded and was evaluated in terms of the inclusion and exclusion criteria. Then irrelevant articles were excluded again.

Table 1. The search strategy in the review.

\begin{tabular}{cc}
\hline 1 & $\begin{array}{c}\text { Climate: OR temperature, OR heat, OR cold, } \\
\text { OR hot, OR ambient temperature, OR weather }\end{array}$ \\
2 & "External cause" \\
3 & 1 and 2 \\
\hline
\end{tabular}


We couldn't find a standard checklist for appraising ecological studies. Nonetheless we evaluated the quality of the selected studies using the methods used in the literature [25] [26]. The articles' quality were assessed by considering: study design, study populations, information about exposure and outcome, statistical methods, measures of air temperature, and adjustment for important confounders such as meteorological factors, long-term trends, and day of the week.

Information was extracted from articles that met the inclusion criteria. A table was created and used to extract information from the studies. Where ever necessary, further information was inquired from the corresponding author of the studies by personal communication. The extracted information included the author, study period, population, study design, exposure and outcome variables, confounders that had been adjusted for, statistical methods and the main result.

\section{Result}

After searching the databases, 696 articles were found and from these, 578 articles were irrelevant according to title and abstract and were discarded. Then from the 65 remaining articles, 52 articles were excluded after reading the full text, because they did not meet the criteria. A large number of articles had excluded mortality due to external cause $(n=23)$ and were therefore excluded from this review. Also many of them had examined the effect of temperature on the number of hospital admissions and not mortality. Four other articles were excluded, because two articles had examined death due to a specific cause (suicide and drowning) separately, and two articles did not have a specific definition of external causes (Figure 1). Finally, 9 articles were included in this study and their characteristics are summarized in Table 1 . There was no eligible article in the reference list of the included studies.

Except two articles, one which was retrospective [27] and the other a case-crossover study [10], the rest of the studies were ecological. In these articles, the impact of 3 different exposure variables had been studied on death due to external causes, which were hot waves, cold waves and daily temperatures (maximum, average). 3 studies had examined the effects of only heat waves [10] [13] [28] and 2 studies had examined the effects of both heat and cold waves [29] [30]. Also, two studies had assessed the mean daily temperature [9] [31] and one study [17] had assessed the maximum daily temperature as the exposure variable. One other study [27] had defined the upper 95 percentile of temperature for 6 weeks, which is similar to the definition of a hot wave, as its exposure variable. This study was published in Russian and information was taken from the abstract and by contacting the author. Three studies considered both death due to external causes (V00 - Y98) and the fatal consequence of external causes (S00 T98) as the outcome of the study [9] [29] [31]. For example, consequences such as injuries or damages that involve different areas of the body and are caused by external causes, were also defined as the outcome. Two of these articles [9] [31] had considered factors influencing health status and reasons for contacting health care services $(Z)$ as an outcome as well. Whereas, this code is not part of 
Records identified throughall databases $(\mathrm{n}=696)$

Scopus $(n=408)$, PubMed $(n=17)$, Science direct $(n=224)$, Web of science $(n=26)$ Embase $(\mathrm{n}=21)$

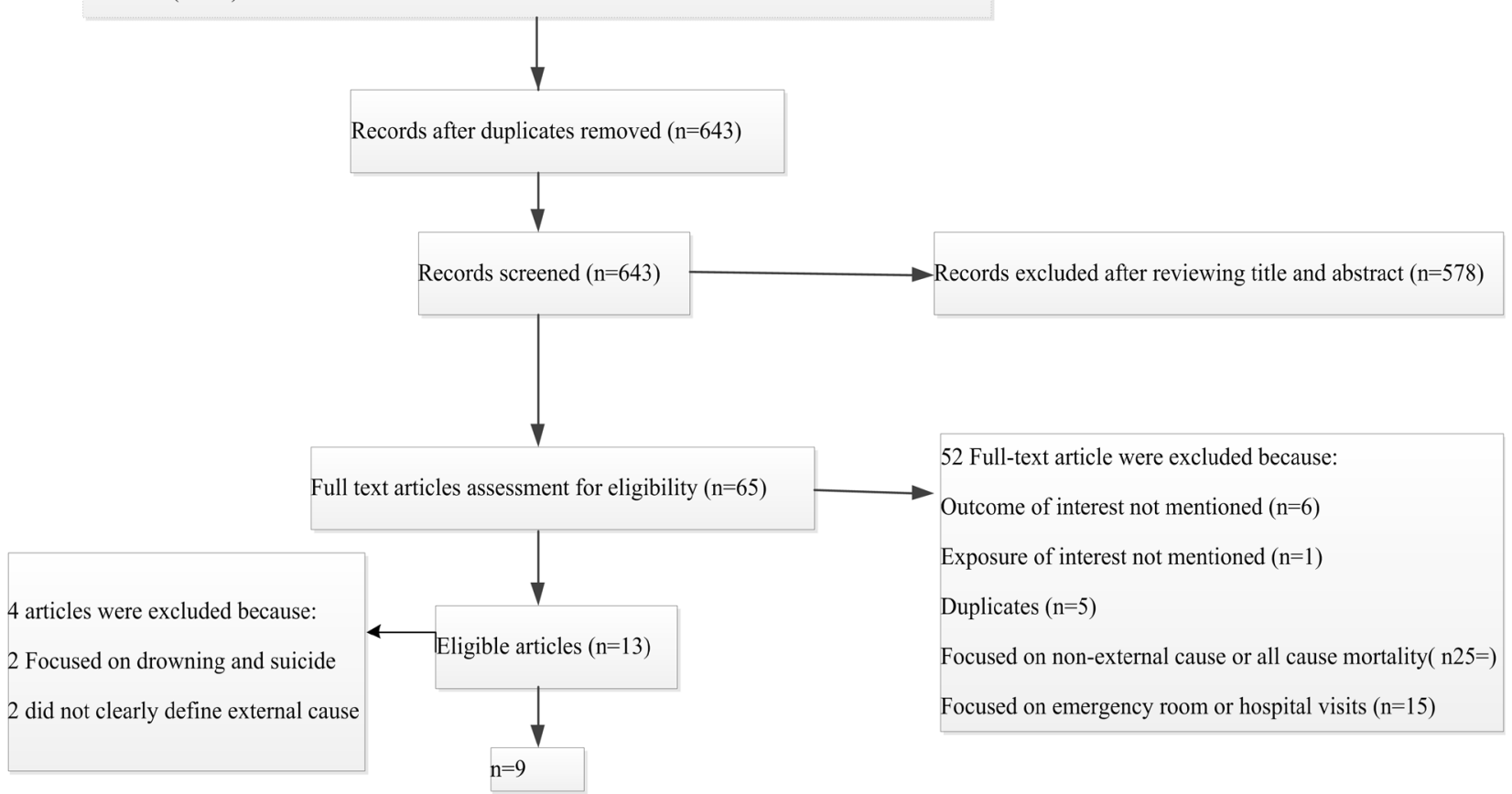

Figure 1. Diagram of study selection.

external causes according to ICD10 and ICD9, and consequence of external causes $(\mathrm{S}-\mathrm{T})$ are separated from death due to external causes $(\mathrm{V}-\mathrm{Y})$ in ICD. Three studies had examined only death due to external causes as the outcome, but only the V00 - Y89 codes were included in the study [10] [13] [28]. From the 9 included studies, only one of them had defined external causes correctly [17]. One article did not mention the codes included in the study [31]. Also two studies had excluded death due to high natural heat (X30), and had analyzed it separately [13] [28].

Except one study [30], all studies had controlled for potential confounders. One study had controlled for only age and sex [28] and two studies had analyzed the relation between temperature and death due to external causes in different age categories. The rest of the studies had adjusted for the variables that had changed over time.

The characteristics of the studies included in this review and their results have been summarized in Table 2. From 6 papers that examined the effect of extreme hot days or heat waves on death due to external cause, 5 showed a significant relation. One study [29] did not find a relation between hot days and mortality due to external causes. As the authors of the study pointed out, their results did not match the results from developed countries. This may be because of the low statistical power of their study, as they mentioned, themselves. Also Hajat [9] and Ishigami [31], used mean ambient temperature, and reported that high temperature was related to mortality due to external causes. Ouro [17] also concluded 
Table 2. Characteristics of included studies.

\begin{tabular}{|c|c|c|c|c|c|c|}
\hline $\begin{array}{c}\text { Authors } \\
\text { (Study period) }\end{array}$ & $\begin{array}{c}\text { Study } \\
\text { population }\end{array}$ & Exposure metrics & $\begin{array}{l}\text { Confounders } \\
\text { that have been } \\
\text { controlled }\end{array}$ & $\begin{array}{l}\text { Outcome } \\
\text { variables } \\
\text { relevant to } \\
\text { this review }\end{array}$ & $\begin{array}{l}\text { Statistical } \\
\text { analysis }\end{array}$ & Main results \\
\hline $\begin{array}{c}\text { Rey et al. } \\
\text { (1971 to 2003) }\end{array}$ & $\begin{array}{c}\text { Whole French } \\
\text { territory }\end{array}$ & $\begin{array}{c}\text { Heat wave } \\
\text { (periods of at least } \\
3 \text { consecutive days } \\
\text { when the maximum } \\
\text { and the minimum } \\
\text { temperature, } \\
\text { averaged over } \\
\text { whole France, were } \\
\text { simultaneously } \\
\text { greater than } \\
\text { their respective } \\
\text { 95th percentile) }\end{array}$ & Age and gender & $\begin{array}{c}\text { Injury and } \\
\text { poisoning } \\
(\mathrm{V} 01-\mathrm{X} 29 \text {, } \\
\mathrm{X} 31-\mathrm{Y} 89) \\
\text { and other } \\
\text { causes } \\
(\text { e.g. } \times 30)\end{array}$ & $\begin{array}{l}\text { The excess } \\
\text { mortality } \\
\text { (observed-expected) } \\
\text { and mortality ratio } \\
\text { (observed/expected) } \\
\text { were calculated for } \\
\text { each cause of death }\end{array}$ & $\begin{array}{l}\text { The greatest excess } \\
\text { mortality }(\mathrm{O}-\mathrm{E}) \text { in } \\
\text { heat waves were } \\
\text { observed for } \\
\text { cardiovascular } \\
\text { diseases, neoplasms, } \\
\text { respiratory system } \\
\text { diseases, HRC } \\
\text { (heat related causes), } \\
\text { ill-defined conditions, } \\
\text { and injury and } \\
\text { poisoning }\end{array}$ \\
\hline $\begin{array}{c}\text { Hajat } \\
\text { et al. } \\
(1993-2003)\end{array}$ & $\begin{array}{l}\text { All regions } \\
\text { of England } \\
\text { and Wales }\end{array}$ & $\begin{array}{c}\text { Mean } \\
\text { temperature }\end{array}$ & $\begin{array}{c}\text { Influenza } \\
\text { epidemics, } \\
\text { ambient levels } \\
\text { of } \mathrm{PM}_{10} \\
\text { (particulate matter) } \\
\text { and ozone }\left(\mathrm{mg} / \mathrm{m}^{3} \text { ) }\right.\end{array}$ & $\begin{array}{c}\text { External } \\
\text { cause of death } \\
\text { (ICD10 codes: } \\
\text { S, T, V, W, X, } \\
\text { Y, Z and ICD9 } \\
\text { codes: } \\
800.0-999.9 \\
\text { or other) }\end{array}$ & $\begin{array}{c}\text { Poisson } \\
\text { generalized } \\
\text { linear models }\end{array}$ & $\begin{array}{l}\text { The greatest risk of } \\
\text { heat mortality was } \\
\text { observed for } \\
\text { respiratory and } \\
\text { external causes }\end{array}$ \\
\hline $\begin{array}{c}\text { Basagana et al. } \\
(1983-2006)\end{array}$ & $\begin{array}{c}\text { Catalonia } \\
\text { region of Spain }\end{array}$ & $\begin{array}{l}\text { Heat waves } \\
\text { (days with } \\
\text { maximum } \\
\text { temperature } \\
\text { above the } \\
\text { 95th percentile) }\end{array}$ & $\begin{array}{c}\text { Humidity and } \\
\text { air pollution (PM) }\end{array}$ & $\begin{array}{l}\text { All external } \\
\text { cause } \\
\text { ICD10 codes } \\
\text { (V01 - Y89) } \\
\text { and ICD9 } \\
\text { codes (E800 - } \\
\text { E999) }\end{array}$ & $\begin{array}{l}\text { Conditional } \\
\text { logistic } \\
\text { regression }\end{array}$ & $\begin{array}{l}\text { Association between } \\
\text { extremely hot days } \\
\text { and mortality was } \\
\text { seen in lag } 0-2 \text { but } \\
\text { was not seen in lag } \\
3 \text { - } 6 \text { for the external } \\
\text { causes category }\end{array}$ \\
\hline $\begin{array}{c}\text { Ingole et al. } \\
\text { (January } 2003 \text { to } \\
\text { December 2012) }\end{array}$ & $\begin{array}{l}\text { Western } \\
\text { India }\end{array}$ & $\begin{array}{l}\text { Heat days } \\
\text { were defined } \\
\text { as days with } \\
\text { maximum } \\
\text { temperatures } \\
\text { above the } 98 \text { th } \\
\text { percentile }\left(>39^{\circ} \mathrm{C}\right) \text {, } \\
\text { and cold days } \\
\text { as days with } \\
\text { maximum } \\
\text { temperatures } \\
\text { below the } 2 \mathrm{nd} \\
\text { percentile }\left(<25^{\circ} \mathrm{C}\right)\end{array}$ & $\begin{array}{l}\text { Day of week; } \\
\text { secular trends and } \\
\text { other time-varying } \\
\text { confounding } \\
\text { factors }\end{array}$ & $\begin{array}{l}\text { External } \\
\text { cause } \\
\text { of death } \\
\text { (ICD } \\
\text { S00 - T98, } \\
\text { V01 - Y98) }\end{array}$ & $\begin{array}{l}\text { Quasi-poisson } \\
\text { regression model }\end{array}$ & $\begin{array}{l}\text { External causes of } \\
\text { death were not } \\
\text { associated with } \\
\text { heat or cold days }\end{array}$ \\
\hline $\begin{array}{l}\text { Ishigami et al. } \\
\text { (Budapest: } \\
\text { 1993-2001 } \\
\text { London: } \\
\text { 1993-2003 } \\
\text { Milan: } \\
\text { 1999-2004) }\end{array}$ & $\begin{array}{l}\text { Three cities } \\
\text { in Europe } \\
\text { (Budapest, } \\
\text { London, } \\
\text { and Milan) }\end{array}$ & $\begin{array}{c}\text { Daily mean } \\
\text { temperature }\left({ }^{\circ} \mathrm{C}\right)\end{array}$ & $\begin{array}{l}\text { Daily ambient levels } \\
\text { of } \mathrm{PM}_{10}\left(\mu \mathrm{g} / \mathrm{m}^{3}\right) \\
\text { (total suspended } \\
\text { particles (TSP) in } \\
\text { Budapest), and } \\
\text { ozone }\left(\mu \mathrm{g} / \mathrm{m}^{3}\right) \\
\text { were obtained } \\
\text { for each city }\end{array}$ & $\begin{array}{c}\text { External } \\
\text { disease } \\
\text { (ICD9 } \\
900.0-999.9 ; \\
\text { ICD10 S, T, } \\
\text { V, W, X, Y, Z) }\end{array}$ & $\begin{array}{l}\text { Poisson generalised } \\
\text { linear models } \\
\text { allowing for } \\
\text { over-dispersion }\end{array}$ & $\begin{array}{c}\text { Effects of high } \\
\text { temperature on death } \\
\text { from external causes } \\
\text { were apparent in all } \\
\text { cities, although not } \\
\text { statistically significant } \\
\text { in Budapest }\end{array}$ \\
\hline
\end{tabular}




\begin{tabular}{|c|c|c|c|c|c|c|}
\hline $\begin{array}{l}\text { Orru et al. } \\
(1997-2013)\end{array}$ & $\begin{array}{c}\text { Northeastern } \\
\text { Europe (Estonia) }\end{array}$ & $\begin{array}{l}\text { Maximum } \\
\text { temperatures }\end{array}$ & $\begin{array}{l}\text { Seasonality and } \\
\text { longer term trends }\end{array}$ & $\begin{array}{l}\text { Deaths from } \\
\text { external } \\
\text { causes } \\
\text { (ICD10 } \\
\text { diagnosis } \\
\text { codes } \\
\text { V00 - Y99) }\end{array}$ & $\begin{array}{l}\text { Poisson regression, } \\
\text { combined with a } \\
\text { distributed lag } \\
\text { non-linear model }\end{array}$ & $\begin{array}{l}\text { External cause } \\
\text { mortality significantly } \\
\text { increased on hot } \\
\text { (the same and previous } \\
\text { day) and cold days } \\
\text { (a lag of } 1-3 \text { days) }\end{array}$ \\
\hline $\begin{array}{l}\text { Joe et al. (18-day } \\
\text { period between } \\
15 \text { July and } \\
1 \text { August, 2006) }\end{array}$ & California & Heat wave & $\begin{array}{c}\text { Underlying } \\
\text { demographics that } \\
\text { may change over } \\
\text { years. } \\
\text { Subgroup analysis in } \\
\text { different age groups } \\
\text { was done }\end{array}$ & $\begin{array}{c}\text { External } \\
\text { causes of death } \\
\text { (ICD10 } \\
\text { V01 to Y89.9) }\end{array}$ & $\begin{array}{c}\text { Simplified } \\
\text { relative risk (RR) } \\
\text { approach } \\
\left(R R=\frac{A_{1}}{A_{0}} / 2\right)\end{array}$ & $\begin{array}{c}\text { Deaths from external } \\
\text { causes increased more } \\
\text { sharply }(\mathrm{RR}=1.18 \\
\text { CI } 1.10-1.27) \text { than } \\
\text { from internal causes } \\
(\mathrm{RR}=1.04 \\
\text { CI } 1.02-1.07)\end{array}$ \\
\hline $\begin{array}{l}\text { Shaposhnikov } \\
\text { et al. (1999-2007) }\end{array}$ & $\begin{array}{l}\text { Four cities in } \\
\text { North Russian } \\
\text { (Archangelsk, } \\
\text { Murmansk, } \\
\text { Yakutsk, } \\
\text { Magadan) }\end{array}$ & $\begin{array}{l}\text { Long and short } \\
\text { temperature waves } \\
\text { defined by daily } \\
\text { mean temperatures } \\
\text { below the cold } \\
\text { threshold } \\
\text { (3rd centile) and } \\
\text { daily mean } \\
\text { temperature } \\
\text { above the heat } \\
\text { threshold } \\
\text { (97th centile) }\end{array}$ & Not mentioned & $\begin{array}{c}\text { All external } \\
\text { causes and all } \\
\text { non-accidental } \\
\text { (non-traumatic) } \\
\text { deaths }\end{array}$ & $\begin{array}{c}\text { Poisson } \\
\text { distributions of } \\
\text { daily deaths; } X^{2} \\
\text { test for frequency } \\
\text { tables based on } \\
\text { city-specific } \\
\text { RR estimates } \\
\text { or fisher's exact } \\
\text { test for the pooled } \\
\text { RR estimates }\end{array}$ & $\begin{array}{l}\text { External causes of } \\
\text { death could be an } \\
\text { important contributing } \\
\text { factor to the rise of } \\
\text { total mortality during } \\
\text { heat waves } \\
\text { (they were responsible } \\
\text { for about } 8 \% \text { of an } \\
\text { increase in total } \\
\text { mortality), while they } \\
\text { are less important } \\
\text { during cold waves } \\
\text { (they caused about } \\
3 \% \text { of an increase) }\end{array}$ \\
\hline $\begin{array}{l}\text { Smirnova et al. } \\
\text { (January } 2010 \text { to } \\
\text { December 2012) }\end{array}$ & $\begin{array}{l}\text { Russia } \\
\text { (Nizhny } \\
\text { Novgorod } \\
\text { Oblast) }\end{array}$ & $\begin{array}{l}\text { Extremely heat } \\
6 \text { week with T } \\
\text { above } 95 \text { th } \\
\text { percentile and } \\
\text { wildfire with } \\
\text { increased } \\
\text { air pollution }\end{array}$ & $\begin{array}{l}\text { Season and other } \\
\text { time-varying } \\
\text { confounding factors }\end{array}$ & $\begin{array}{l}\text { External cause } \\
\text { of death } \\
\text { (ICD10 codes: } \\
\text { T58; } \\
\text { T29-32, } \\
\text { C76.8) }\end{array}$ & $\begin{array}{c}2 \times 2 \text { and } 2 \times 3 \\
\text { contingency tables; } \\
\text { the } X^{2}(X \text { squared }) \\
\text { Pearson criterion }\end{array}$ & $\begin{array}{l}\text { The period of AH } \\
\text { (Abnormal Heat) } \\
\text { was followed by an } \\
\text { increase of mortality } \\
\text { from external causes } \\
\text { ( } \mathrm{p}<0.01 \text { ) comparing } \\
\text { to the summer } 2011\end{array}$ \\
\hline
\end{tabular}

that hot days, which were defined using maximum daily temperature, significantly increased mortality due to external causes. Rey [28] and Joey [13], despite the fact that they excluded death due to excessive natural heat (X30), saw a significant relation between deaths due to external causes and heat.

It seems that the effect of cold days on mortality due to external causes is less significant. One study [30] had shown that the proportion of death due to external causes is small in comparison to death due to all causes during cold waves (about 3\%). Ingole et al. [29] did not see any relation between cold waves and death due to external causes. But one study [17] that had defined exposure correctly, found a significant relation and death due to external causes increased on cold days.

\section{Discussion}

As far as we know this is the first literature review done about the relation be- 
tween temperature and death due to all external causes together. This review suggests that high temperatures are probably more related to deaths due to external causes than low temperatures. Rey et al. [28] despite excluding deaths due to excessive natural heat (X30), observed the greatest excess mortality for other deaths(ICD: O - E) due to external causes. Similarly, Joe et al. excluded deaths due to excessive natural heat and still observed a direct relation between temperature and deaths due to external causes.

The results of studies that have addressed death due to one or more external causes separately, are consistent with these results. For example, several studies have examined the effect of temperature on death due to suicide and have shown that high temperatures are associated with an increase in suicides [32] [33] [34]. Also studies that have examined the effects of temperature on road accidents have also concluded that high temperatures increase crashes [1] [35]. In a review conducted by Campe et al., from 13 studies that were included, 11 of them showed an increase in unintentional injuries related to high temperatures [16].

In the present review, due to the small number of studies about the effect of cold or low temperature on deaths due to external causes, it is difficult to conclude how cold is associated with death due to external causes. Most studies that have investigated death due to specific external causes have also focused more on high than low temperatures [36]. Therefore, further investigation on the effects of cold is needed. A study conducted by Ingole et al. [29] did not show any significant effect of cold in three different lags $(0,0-4,0$ - 14) on death due to external causes. However, this study had used oral autopsy for data collection and included only deaths in which an oral autopsy with the deceased person's family member had been done.

Shaposhnikov et al.'s study showed that although death due to external causes had a significant relation with cold waves, but this relation was weak. They showed that the age group over 65 was more vulnerable to cold than the younger group (under 65). A study conducted by Ishigami et al. [31] showed that deaths due to external causes are associated with both age and high temperature, and as age increases, the risk of death increases more steeply. But Hajat et al. reported that the highest risk of death due to high temperature happened in the 0 - 64 age group [9]. Considering this point is necessary that if deaths due to specific external causes (for example deaths from road crashes, get studied separately; the results may be different. For example in a study conducted by Ishigami et al., the younger age group was at a higher risk of deaths due to road traffic injuries, falls and drowning related to high temperature, than the elderly. This is probably due to the fact that younger people are more likely to seek adventure and encounter external causes than the elderly.

Increased mortality due to external causes at high temperatures is justifiable through mechanisms and intermediate variables and also depends on the specific cause. For example, road accidents, which account for a large proportion of deaths due to external causes in some countries, can occur due to changes in road or car conditions that happen in high temperatures [37] [38]. Also it can 
occur due to changes in human behavior in hot temperatures [17]. For example high temperatures reduce people's performance and skill in doing their routine work and the risk of unintentional injuries, such as work accidents or occupational injuries, increases. One of the other reasons is that recreational activities such as swimming increase in hot temperatures, and this increases the risk of drowning. Also outdoor fires occur more frequently in high temperatures [16] [39].

Some studies have shown that injuries occur more on certain times of the year and locations. For example a study conducted in British Columbia [40] showed that the majority of injuries occurred in the afternoon and on weekends. They also showed fatal incidents most often occurred during summer (particularly in the month of August) and the majority of fatalities occurred during daylight hours, and on dry roads. They recommended prevention programs such as strengthening individual knowledge and skills, promoting community education, and changing organization practices. Also special safety laws and regulations are needed for injury prevention in specific seasons, and weather conditions. For example safety tips are recommended for safe driving in the cold season. Although recommendations have been made for certain causes such as drowning in the hot season as well, this review shows that the heat season needs more attention to prevent accidents and injuries.

Some population subgroups are more vulnerable to injuries than others. A study that assessed the association between high temperature and work-related injuries in Australia [41], mentioned that people working outdoors are at high risk of weather-related heat exposure and male workers, young workers aged $\leq$ 24 years, those working in industries such as "agriculture, forestry and fishing", "construction" and "electricity, gas and water", laborers, production and transport workers, and tradespersons in small and medium-sized businesses were more vulnerable than others. Therefore, industry-specific and hot-weather alert and response mechanisms need to be developed through multi-sector cooperation to improve risk perceptions and knowledge of vulnerable groups about minimizing harm strategies during extremely hot weather.

However, the results of this review are not enough for making concrete conclusions, and further studies are needed to determine the relation between temperature and death due to external causes. Most studies about the effects of ambient temperature have excluded death due to external causes. Moreover, due to inaccuracy in recording the causes of death in some countries, it is possible that death due to external causes may have been underestimated [42] [43]. One reason maybe because the consequence of these external causes (Chapter 19 of ICD10 book) was recorded as the main cause of death, instead of the external cause itself (Chapter 20 of ICD10). This may lead to inaccuracy of the estimates in investigating the relation between mortality due to external causes and its risk factors. Therefore, the results of these studies should be interpreted cautiously.

A limitation of this review is that due to the ecological nature of most of the articles included in this study, their quality was not evaluated using an existing 
standard checklist. It is suggested that more robust studies be done in this field.

\section{Conclusions}

The results of this systematic review show that high temperatures (heat) are more likely to cause mortality due to external causes than low temperatures. Considering the increase in average global temperature and the increasing number of deaths due to high temperature in many parts of the world, effective intervention programs are need to raise awareness among people, especially vulnerable groups such as specific job groups, children, people with disabilities, and the elderly to prevent and reduce the adverse effects of high temperatures.

However, there were a small number of studies about cold and death due to external causes, and further studies about this topic should be done.

\section{Acknowledgements}

This study was financially supported by Kerman University of Medical Sciences, Kerman, Iran.

\section{Ethical Issues}

Not Applicable.

\section{Competing Interests}

Authors state no conflict of interest.

\section{Authors' Contributions}

All authors contributed equally and participated in the study design, data collection, and writing the final article.

\section{References}

[1] Wang, YC. and Lin, YK. (2014) Association between Temperature and Emergency Room Visits for Cardiorespiratory Diseases, Metabolic Syndrome-Related Diseases, and Accidents in Metropolitan Taipei. PLoS ONE, 9, e99599. https://doi.org/10.1371/journal.pone.0099599

[2] Ma, P., Wang, S., Fan, X. and Li, T. (2016) The Impacts of Air Temperature on Accidental Casualties in Beijing, China. International Journal of Environmental Research and Public Health, 11, 1073-1086. https://doi.org/10.3390/ijerph13111073

[3] Dadbakhsh, M., Khanjani, N., Bahrampour, A. and Haghighi, PS. (2017) Death from Respiratory Diseases and Temperature in Shiraz, Iran (2006-2011). International Journal of Biometeorology, 61, 239-246. https://doi.org/10.1007/s00484-016-1206-Z

[4] Sharafkhani, R., Khanjani, N., Bakhtiari, B., Jahani, Y. and Entezar, M.R. (2017) Diurnal Temperature Range and Mortality in Urmia, the Northwest of Iran. Journal of Thermal Biology, 69, 281-287. https://doi.org/10.1016/j.jtherbio.2017.08.011

[5] Khanjani, N. and Bahrampour, A. (2013) Temperature and Cardiovascular and Respiratory Mortality in Desert Climate. A Case Study of Kerman, Iran. Iranian 
Journal of Environmental Health Science \& Engineering, 10, 11.

[6] Burkart, K. and Kinney, P. (2016) Is Precipitation a Predictor of Mortality in Bangladesh? A Multi-Stratified Analysis in a South Asian Monsoon Climate. Science of the Total Environment, 553, 458-465.

https://doi.org/10.1016/j.scitotenv.2016.01.206

[7] Ravandi, M.R.G., Salimi, S., Khanjani, N. and Jafari, M.J. (2016) Comparing the Association between Wet Bulb Globe Temperature (WBGT) and Heat Stress Score Index (HSSI) Thermal Indices with Physiological Parameters in a Melting Plant. International Journal of Occupational Hygiene, 8, 9-13.

[8] Gonsaga, R.A.T., Rimoli, C.F., Pires, E.A., Zogheib, F.S., Fujino, M.V.T. and Cunha, M.B. (2012) Evaluation of the Mortality Due to External Causes. Revista do Colégio Brasileiro de Cirurgióes, 39, 263-267. https://doi.org/10.1590/S0100-69912012000400004

[9] Hajat, S., Kovats, R.S. and Lachowycz, K. (2007) Heat-Related and Cold-Related Deaths in England and Wales: Who Is at Risk? Occupational and Environmental Medicine, 64, 93-100. https://doi.org/10.1136/oem.2006.029017

[10] Basagaña, X., Sartini, C., Barrera-Gómez, J., Dadvand, P., Cunillera, J., Ostro, B., et al. (2011) Heat Waves and Cause-Specific Mortality at All Ages. Epidemiology, 22, 765-772. https://doi.org/10.1097/EDE.0b013e31823031c5

[11] Center for Disease Control and Prevention (2017) National Center for Health Statistics. https://www.cdc.gov/nchs/icd/icd9cm_addenda_guidelines.htm

[12] WHO (2017) International Statistical Classification of Diseases and Related Health Problems, 10th Revision. http://apps.who.int/classifications/icd10/browse/2010/en

[13] Joe, L., Hoshiko, S., Dobraca, D., Jackson, R., Smorodinsky, S., Smith, D., et al. (2016) Mortality during a Large-Scale Heat Wave by Place, Demographic Group, Internal and External Causes of Death, and Building Climate Zone. International Journal of Environmental Research and Public Health 3, 299-315. https://doi.org/10.3390/ijerph13030299

[14] Helama, S., Holopainen, J. and Partonen, T. (2013) Temperature-Associated Suicide Mortality: Contrasting Roles of Climatic Warming and the Suicide Prevention Program in Finland. Environmental Health and Preventive Medicine, 18, 349-355. https://doi.org/10.1007/s12199-013-0329-7

[15] Kalankesh, L.R., Mansouri, F. and Khanjani, N. (2015) Association of Temperature and Humidity with Trauma Deaths. Trauma Monthly, 20, 1-5. https://doi.org/10.5812/traumamon.23403

[16] im Kampe, E.O., Kovats, S. and Hajat, S. (2016) Impact of High Ambient Temperature on Unintentional Injuries in High-Income Countries: A Narrative Systematic Literature Review. BMJ Open, 6, e010399.

https://doi.org/10.1136/bmjopen-2015-010399

[17] Orru, H. and Astrom, D.O. (2016) Increases in External Cause Mortality Due to High and Low Temperatures: Evidence from Northeastern Europe. International Journal of Biometeorology, 5, 963-966.

[18] Ahmadnezhad, E., Holakouie Naieni, K., Ardalan, A., Mahmoudi, M., Yunesian, M., Naddafi, K., et al. (2013) Excess Mortality during Heat Waves, Tehran Iran: An Ecological Time-Series Study. Journal of Research in Health Sciences, 13, 24-31.

[19] Tong, S., Wang, X.Y. and Guo, Y. (2012) Assessing the Short-Term Effects of Heatwaves on Mortality and Morbidity in Brisbane, Australia: Comparison of Case-Crossover and Time Series Analyses. PLoS ONE, 7, e37500. 
[20] Wang, Y.C., Lin, Y.K., Chuang, C.Y., Li, M.H., Chou, C.H., Liao, C.H., et al. (2012) Associating Emergency Room Visits with First and Prolonged Extreme Temperature Event in Taiwan: A Population-Based Cohort Study. Science of the Total Environment, 416, 97-104. https://doi.org/10.1016/j.scitotenv.2011.11.073

[21] Kim, Y., Kim, H. and Kim, D.S. (2011) Association between Daily Environmental Temperature and Suicide Mortality in Korea (2001-2005). Psychiatry Research, 186, 390-396. https://doi.org/10.1016/j.psychres.2010.08.006

[22] Dixon, P.G., McDonald, A.N., Scheitlin, K.N., Stapleton, J.E., Allen, J.S., Carter, W.M., et al. (2007) Effects of Temperature Variation on Suicide in Five US Counties, 1991-2001. International Journal of Biometeorology, 51, 395-403. https://doi.org/10.1007/s00484-006-0081-4

[23] Christodoulou, C., Douzenis, A., Papadopoulos, F.C., Papadopoulou, A., Bouras, G., Gournellis, R., et al. (2012) Suicide and Seasonality. Acta Psychiatrica Scandinavica, 125, 127-146. https://doi.org/10.1111/j.1600-0447.2011.01750.x

[24] Deisenhammer, E.A. (2003) Weather and Suicide: The Present State of Knowledge on the Association of Meteorological Factors with Suicidal Behaviour. Acta Psychiatrica Scandinavica, 108, 402-409. https://doi.org/10.1046/j.0001-690X.2003.00209.x

[25] Lian, H., Ruan, Y., Liang, R., Liu, X. and Fan, Z. (2015) Short-Term Effect of Ambient Temperature and the Risk of Stroke: A Systematic Review and Meta-Analysis. International Journal of Environmental Research and Public Health, 12, 9068-9088. https://doi.org/10.3390/ijerph120809068

[26] Pieters, N., Plusquin, M., Cox, B., Kicinski, M., Vangronsveld, J. and Nawrot, T.S. (2012) An Epidemiological Appraisal of the Association between Heart Rate Variability and Particulate Air Pollution: A Meta-Analysis. Heart, 98, 1127-1135. https://doi.org/10.1136/heartjnl-2011-301505

[27] Smirnova, M.D., Badin Y.V., Badina O.Y., Vaisberg A.R., Polyakov, D.S., Shcherbinina, E.V., Ageev, F.T. and Fomin, F.T. (2015) Evaluation of the Short-Term and Delayed Risks of the Abnormal Summer 2010 Heat Impact in Several Districts of Nizhny Novgorod Oblast, Close to Wildfires, on the Morbidity and Mortality of Inhabitants. Cardiovascular Therapy and Prevention, 6, 59-65. https://doi.org/10.15829/1728-8800-2015-6-59-65

[28] Rey, G., Jougla, E., Fouillet, A., Pavillon, G., Bessemoulin, P., Frayssinet, P., et al. (2007) The Impact of Major Heat Waves on All-Cause and Cause-Specific Mortality in France from 1971 to 2003. International Archives of Occupational and Environmental Health, 80, 615-626. https://doi.org/10.1007/s00420-007-0173-4

[29] Ingole, V., Rocklöv, J., Juvekar, S. and Schumann, B. (2015) Impact of Heat and Cold on Total and Cause-Specific Mortality in Vadu HDSS-A Rural Setting in Western India. International Journal of Environmental Research and Public Health, 12, 15298-15308. https://doi.org/10.3390/ijerph121214980

[30] Shaposhnikov, D. and Revich, B. (2016) Toward Meta-Analysis of Impacts of Heat and Cold Waves on Mortality in Russian North. Urban Climate, 15, 16-24. https://doi.org/10.1016/j.uclim.2015.11.007

[31] Ishigami, A., Hajat, S., Kovats, R.S., Bisanti, L., Rognoni, M., Russo, A., et al. (2008) An Ecological Time-Series Study of Heat-Related Mortality in Three European Cities. Environmental Health, 7, 5-12. https://doi.org/10.1186/1476-069X-7-5

[32] Grjibovski, A.M., Kozhakhmetova, G., Kosbayeva, A. and Menne, B. (2013) Associations between Air Temperature and Daily Suicide Counts in Astana, Kazakhstan. Medicina-Lithuania, 49, 379-385. https://doi.org/10.3390/medicina49080059 
[33] Gaxiola-Robles, R., de la Rosa, A.D., Labrada-Martagon, V., Diaz-Castro, S.C. and Zenteno-Savin, T. (2013) Environmental Temperature Increase and Its Possible Association with Suicide in the Population of Baja California Sur (BCS) 1985-2008. Salud Mental, 36, 421-427. https://doi.org/10.17711/SM.0185-3325.2013.053

[34] Kim, Y., Kim, H., Honda, Y., Guo, Y.L., Chen, B.Y., Woo, J.M., et al. (2016) Suicide and Ambient Temperature in East Asian Countries: A Time-Stratified Case-Crossover Analysis. Environmental Health Perspectives, 124, 75-80.

[35] Basagaña, X., Escalera-Antezana, J.P., Dadvand, P., Llatje, Ó., Barrera-Gómez, J., Cunillera, J., et al. (2015) High Ambient Temperatures and Risk of Motor Vehicle Crashes in Catalonia, Spain (2000-2011): A Time-Series Analysis. Environmental Health Perspectives, 123, 1309-1316.

[36] Basu, R. (2009) High Ambient Temperature and Mortality: A Review of Epidemiologic Studies from 2001 to 2008. Environmental Health, 8, 40-53.

https://doi.org/10.1186/1476-069X-8-40

[37] Liu, A., Soneja, S.I., Jiang, C., Huang, C., Kerns, T., Beck, K., et al. (2017) Frequency of Extreme Weather Events and Increased Risk of Motor Vehicle Collision in Maryland. Science of the Total Environment, 580, 550-555. https://doi.org/10.1016/j.scitotenv.2016.11.211

[38] Dastoorpoor, M., Idani, E., Khanjani, N., Goudarzi, G. and Bahrampour, A. (2016) Relationship between Air Pollution, Weather, Traffic, and Traffic-Related Mortality. Trauma Monthly, 21, e37585.

[39] Shirreffs, S.M. (2005) The Importance of Good Hydration for Work and Exercise Performance. Nutrition Reviews, 63, 14-21.

[40] Desapriya, E., Sones, M., Ramanzin, T., Weinstein, S., Scime, G. and Pike, I. (2011) Injury Prevention in Child Death Review: Child Pedestrian Fatalities. Injury Prevention, 17, 4-9. https://doi.org/10.1136/ip.2010.026914

[41] Xiang, J., Bi, P., Pisaniello, D., Hansen, A. and Sullivan, T. (2014) Association between High Temperature and Work-Related Injuries in Adelaide, South Australia, 2001-2010. Occupational \& Environmental Medicine, 71, 246-252. https://doi.org/10.1136/oemed-2013-101584

[42] Bugeja, L., Clapperton, A.J., Killian, J.J., Stephan, K.L. and Ozanne-Smith, J. (2010) Reliability of ICD-10 External Cause of Death Codes in the National Coroners Information System. Health Information Management Journal, 39, 16-26. https://doi.org/10.1177/183335831003900303

[43] McKenzie, K., Enraght-Moony, E.L., Walker, S.M., McClure, R.J. and Harrison, J.E. (2009) Accuracy of External Cause-of-Injury Coding in Hospital Records. Injury Prevention, 15, 60-64. https://doi.org/10.1136/ip.2008.019935 


\section{Supplementary}

Table S1. Search strategy and search terms used in the databases.

\begin{tabular}{|c|c|c|c|c|c|}
\hline \multirow{2}{*}{ Search set } & \multicolumn{5}{|c|}{ Data base } \\
\hline & Pubmed & Embase & Scopus & Web of Science & Science Direct \\
\hline$\# 1$ & climate & climate & climate & climate & climate \\
\hline$\# 2$ & weather & weather & weather & weather & weather \\
\hline$\# 3$ & $\begin{array}{l}\text { Ambient } \\
\text { temperature }\end{array}$ & $\begin{array}{l}\text { Ambient } \\
\text { temperature }\end{array}$ & $\begin{array}{l}\text { Ambient } \\
\text { temperature }\end{array}$ & $\begin{array}{l}\text { Ambient } \\
\text { temperature }\end{array}$ & $\begin{array}{l}\text { Ambient } \\
\text { temperature }\end{array}$ \\
\hline$\# 4$ & temperature & temperature & temperature & temperature & temperature \\
\hline$\# 5$ & heat & heat & heat & heat & heat \\
\hline \#6 & hot & hot & hot & hot & hot \\
\hline \multirow[t]{2}{*}{ \#7 } & cold & cold & cold & cold & cold \\
\hline & $\# 1 \mathrm{OR} \# 2$ OR & $\# 1 \mathrm{OR} \# 2$ OR & $\# 1 \mathrm{OR} \# 2$ OR & $\# 1 \mathrm{OR} \# 2$ OR & \#1 OR \#2 OR \\
\hline \multirow[t]{2}{*}{$\# 8$} & $\# 3$ OR \#4 OR & \#3 OR \#4 OR & $\# 3$ OR \#4 OR & $\# 3$ OR \#4 OR & \#3 OR \#4 OR \\
\hline & \#5 OR \#6 OR \#7 & $\# 5$ OR \#6 OR \#7 & $\# 5$ OR \#6 OR \#7 & $\# 5$ OR \#6 OR \#7 & $\# 5$ OR \#6 OR \#7 \\
\hline$\# 9$ & "external cause" & "external cause" & "external cause" & "external cause" & "external cause" \\
\hline \#10 & $\# 8$ and $\# 9$ & $\# 8$ and \#9 & $\# 8$ and $\# 9$ & $\# 8$ and $\# 9$ & $\# 8$ and $\# 9$ \\
\hline
\end{tabular}

The same terms were applied in each databases. The searches were done without any limitation in search field (Title, Abstract, Key word, ...). 